\title{
Parasite communities of the predatory fish, Acestrorbynchus falcatus and Acestrorbynchus falcirostris, living in sympatry in Brazilian Amazon
}

\author{
Comunidades de parasitos dos peixes predadores, Acestrorhynchus falcatus and Acestrorhynchus falcirostris, \\ vivendo em simpatria na Amazônia brasileira
}

\author{
Maria Danielle Figueiredo Guimarães Hoshino ${ }^{1}$; Lígia Rigôr Neves ${ }^{2}$ Marcos Tavares-Dias ${ }^{1,2,3 *}$
}

${ }^{1}$ Programa de Pós-graduação em Biodiversidade Tropical - PPGBIO, Universidade Federal do Amapá - UNIFAP, Macapá, AP, Brasil
${ }^{2}$ Programa de Pós-graduação da Rede de Biodiversidade e Biotecnologia da Amazônia Legal - Bionorte, Universidade Federal do
Amapá - UNIFAP, Macapá, AP, Brasil
${ }^{3}$ Embrapa Amapá, Macapá, AP, Brasil

Received March 10, 2016

Accepted May 3, 2016

\begin{abstract}
This study investigated the parasite communities of wild Acestrorhynchus falcatus and Acestrorhynchus falcirostris populations living in sympatry in Brazilian Amazon. In these two hosts, a total of 12 parasite species e 1-9 parasite species were found per fish, and 10 of these species are metazoans. Eight species of parasites were common to both host species and four of them exhibited differences in abundance and/or prevalence. Parasite communities of the hosts were taxonomically similar (83\%) and composed of both ectoparasites and endoparasites, and characterized by high prevalence and high abundance of endoparasites and an aggregated dispersion pattern. For A. falcirostris, the dominant parasite was Ichthyophthirius multifliiis, and for A. falcatus, it was Piscinoodinium pillulare. Shannon diversity and Berger-Parker dominance were similar for both hosts, while the parasites species richness and evenness showed differences influenced by the ectoparasites species. These two populations of hosts that inhabited the same geographical area had different sizes, but were exposed to the same infective stages, and acquired qualitatively and quantitatively similar endoparasites community, thus indicating that the amounts and types of prey congeneric that they were eating were similar. Therefore, the overlap in the same occurrence area play an important role in the parasite communities to these phylogenetically related hosts.
\end{abstract}

Keywords: Aggregation, ectoparasites, freshwater fish, infection, helminths.

\section{Resumo}

Este estudo investigou as comunidades parasitárias de populações naturais de Acestrorhynchus falcatus e Acestrorhynchus falcirostris, peixes piscívoros filogeneticamente relacionados e vivendo em simpatria na Amazônia brasileira. Nessas duas espécies de hospedeiros foram encontradas um total de 12 espécies de parasitos, 1-9 espécies de parasitos por peixe, e desse total de espécies de parasitos, 10 são metazoários. Oito espécies de parasitos foram comuns às duas espécies de hospedeiros e quatro deles apresentaram diferenças na abundância e/ou prevalência. As comunidades parasitárias desses hospedeiros foram taxonomicamente similares (83\%) e compostas de ectoparasitos e endoparasitos, mas foram caracterizados por elevada prevalência e elevada abundância de endoparasitos com padrão de dispersão agregado. Para $A$. falcirostris, Ichthyophthirius multifliis foi o parasito dominante, mas para A. falcatus foi Piscinoodinium pillulare. O índice de diversidade de Shannon e a dominância de Berger-Parker foram similares para ambos hospedeiros, enquanto a riqueza de espécies de parasitos e uniformidade apresentaram diferenças influenciadas pelas espécies de ectoparasitos. Estas duas populaçôes de hospedeiros congenéricos que habitavam a mesma área geográfica tinham tamanhos diferentes, mas foram expostos aos mesmos estágios infectantes, adquirindo uma comunidade de endoparasitos qualitativa e quantitativamente similar, indicando assim que as quantidades e tipos de presa que eles estavam ingerindo foram similares. Portanto, a sobreposição em uma mesma área de ocorrência desempenhou um papel importante nas comunidades de parasitos para estes hospedeiros relacionados filogeneticamente.

Palavras-chave: Agregação, ectoparasitos, peixes de água doce, infecção, helmintos.

\footnotetext{
*Corresponding author: Marcos Tavares-Dias. Embrapa Amapá, Rodovia Juscelino Kubitschek, Km 5, 2600, CEP 68903-419, Macapá, AP, Brasil.

e-mail: marcos.tavares@embrapa.br
} 


\section{Introduction}

Acestrorhynchus Eigenmann and Kennedy 1903, is the single genus of family Acestrorhynchidae Eigenmann 1912, which is formed by 15 valid species of Neotropical fish that are endemic to South America (TOLEDO-PIZA, 2007; PRETTI et al., 2009; FROESE \& PAULY, 2016). The species of Acestrorhynchidae are of interest because they belong to a monophyletic taxon and presented a high degree of endemism to Amazon, Orinoco, São Francisco, Paraná, Paraguay basins and La Plata drainages (SILVA \& GOITEIN, 2009; TOLEDO-PIZA, 2007; PRETTI et al., 2009; FROESE \& PAULY, 2016). These species are found in a variety of habitats, but primarily live in lakes in areas near the shores of the Amazon River and Orinoco River systems, and the smallest species are especially found in small creeks (igarapés). Among the Amazonian species are Acestrorhynchus falcatus Bloch 1794, and Acestrorhynchus falcirostris Cuvier 1819, which are the fish of the present study, which are not listed by the IUCN as endangered species.

Acestrorhynchus falcatus and A. falcirostris are benthopelagic, sedentary and diurnal fish. They are piscivorous, but young individuals may also eat shrimps. Acestrorhynchus falcatus has a standard length of around $30 \mathrm{~cm}$, while $A$. falcirostris may reach a standard length of around $40 \mathrm{~cm}$. However, in both species, the females start their first sexual maturity when they reach a standard length of $14 \mathrm{~cm}$. They spawn in batches, and reproduction occurs with greater intensity at the end of the dry period (December) and at the beginning of the flood period (May) in the Amazon region (SOARES et al., 2011). These host fish can therefore be infected by various taxa of endoparasites, since their diet includes invertebrate species and also small fish that feed on different invertebrates. The acestrorhynchids are not commercially important as food fish, but might be eventually found in aquarium shops.

Parasitism has been implicated as an important factor in the population dynamics of fish species (POULIN \& FITZGERALD, 1987; ALCÂNTARA \& TAVARES-DIAS, 2015; PANTOJA et al., 2016). The parasites can be found in host communities and coexists in the same individual of a single host fish species, or in different host fish species (MUÑOZ et al., 2006; TAVARES \& LUQUE, 2008; ALARCOS \& TIMI, 2012). Thus, explaining the drivers of species diversity is a major matter within ecological and evolutionary research. Host fish species that are phylogenetically close tend to present parasite diversity and species richness of greater similarity than those of unrelated host species (MUNOZZ et al., 2006; ALARCOS \& TIMI, 2012; PANTOJA et al., 2016). Congeneric hosts mostly have similar ecology, and thus can overlap in space and time. The biggest problem is to determine where and how this overlapping occurs (TAVARES \& LUQUE, 2008; ALARCOS \& TIMI, 2012; PANTOJA et al., 2016). For host fish populations living in sympatry the similarity in parasite assemblages has been investigated (MUNOZZ et al., 2006; ALARCOS \& TIMI, 2012; PANTOJA et al., 2016). However, this subject has not been addressed in relation to freshwater fish populations in the Amazon region, such as acestrorhynchid species.

In phylogenetically related species, host-parasite coevolution, exposure to parasites and the likelihood that hosts will encounter parasites are factors that influence the vulnerability of fish and the levels of parasite infection (GUIDELLI et al., 2006; GONZÁLEZ \& OLIVA, 2006; PANTOJA et al., 2016). Nevertheless, the main factors that control the structure of endoparasites communities and the levels of parasitism are generally ecological (age, size, habitat, trophic level, vagility, schooling behavior, reproductive season and population size, etc.). Thus, for parasites acquired through the trophic chain (endohelminths), the possibility of host-parasite encounters is the main factor determining the richness and diversity of parasite species (MUÑOZ et al., 2006; ALARCOS \& TIMI, 2012; NEVES et al., 2013; PANTOJA et al., 2016). However, ectoparasites communities are affected by the habitat, behavior and density of the host, as well as by environmental characteristics (GONZÁLEZ \& OLIVA, 2006).

One way of assessing the similarity of parasite community structures in fish and the ecological factors relating to them is to examine the effects of the ecology and phylogeny on parasite richness and abundance in phylogenetically related hosts that live in the same geographical area (POULIN \& FITZGERALD, 1987; GUIDELLI et al., 2006; MUÑOZ et al., 2006; GONZÁLEZ \& OLIVA, 2006; ALARCOS \& TIMI, 2012; PANTOJA et al., 2016). Thus, to determine whether species of Acestrorhynchidae that live in the same environment and are phylogenetically related have similar parasite communities, we surveyed the ectoparasites and endoparasites of two closely related hosts, $A$. falcirostris and $A$. falcatus, which are congeneric sympatric fish inhabiting the eastern Amazon region (Northern Brazil). Thus, the aim of this study was to comparate the parasite communities of $A$. falcatus and A. falcirostris population living in sympatry in Brazilian Amazon. These two hosts were captured in the Igarapé Fortaleza basin, an important tributary of the Amazon River system, in eastern Amazon (Brazil), which is highly influenced by the Amazon River system. It consists of linked fluvial physical systems that provide freshwater drainage, and is influenced by the high rainfall of the Amazon region and the daily tides of the Amazon River. The waters that periodically spread out across the floodplain are rich in nutrients, because of the rapid decomposition of grasses, animal remains and the humus layer of the forest. This leads to growth of new vegetation (Poaceae, Cyperaceae, Fabaceae, Onagraceae, Araceae, Asteraceae, Convolvulaceae and Lentibulariaceae) and invertebrates biomass (insects, zooplanktonic crustaceans and mollusks), which are used as food by the fish (GAMA \& HALBOTH, 2004; TAKIYAMA et al., 2012).

\section{Materials and methods}

\section{Study area and fish collection}

Between April and December 2011, 61 specimens of Acestrorhynchus falcatus and 33 specimens of Acestrorhynchus falcirostris were caught in the basin of Igarapé Fortaleza (Figure 1), in the region of Macapá, state of Amapá (Brazil). The fish were caught in gillnets of different mesh sizes (ICMBio authorization number: 23276-1) and were then stored in insulated boxes containing ice and transported to the Laboratory for Aquatic Organism Health at Embrapa Amapá, for analyses on the parasites. This study was developed in accordance with the principles adopted by the Brazilian College of Animal Experimentation (COBEA). 


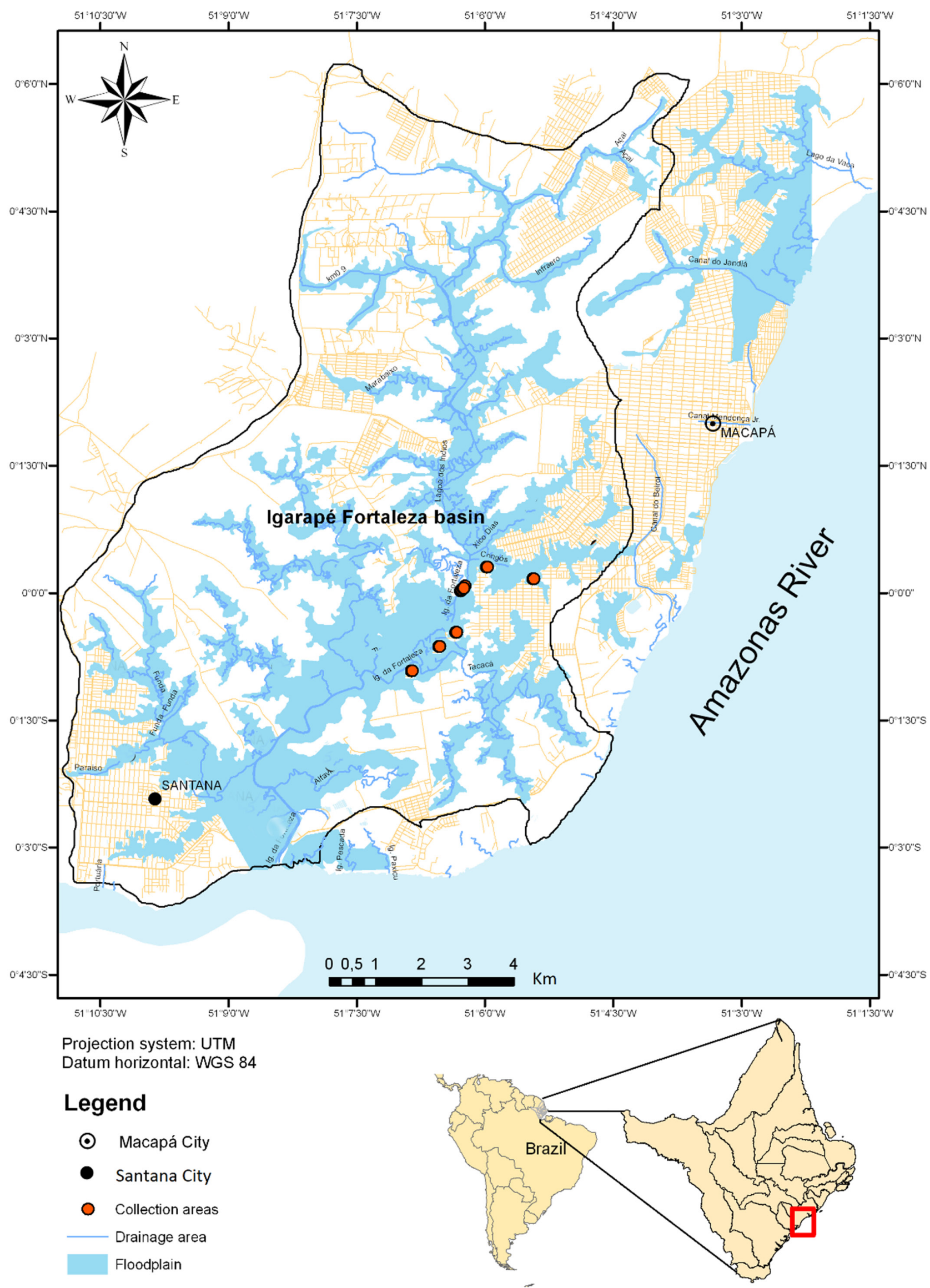

Figure 1. Collection sites of the two Acestrorhynchidae species from Brazilian Amazon. 


\section{Parasite collection and analysis procedures}

The fish caught were weighed $(\mathrm{g})$ and their total length was measured $(\mathrm{cm})$. Each specimen was then evaluated macroscopically, observing the body surface, mouth, eyes, opercula and gills. The gills were removed to collect ectoparasites. The gastrointestinal tract and viscera was removed and examined in order to collect endoparasites. The parasite specimens were collected, fixed, quantified and stained for identification (EIRAS et al., 2006).

The ecological terms used followed previous recommendations (ROHDE et al., 1995; BUSH et al., 1997). The Shannon diversity index $(H)$, evenness $(E)$, Berger-Parker dominance index $(d)$ and species richness (MAGURRAN, 2004) were calculated for each component parasite community, using the Diversity software (Pisces Conservation Ltd, UK). The dispersion index (DI) and discrepancy index (D) were calculated using the Quantitative Parasitology 3.0 software, in order to detect the distribution pattern of the parasite infracommunities (RÓZSA, et al., 2000), for species with prevalence $>10 \%$. The significance of DI, for each infracommunity, was tested using the $d$ statistic (LUDWIG $\&$ REYNOLDS, 1988). For similarity measurements on parasites abundance between $A$. falcirostris and $A$. falcatus, the Jaccard index (qualitative index) and Bray-Curtis index (quantitative index) were used. These parameters take into account differences in abundance among the shared parasite species (LUDWIG \& REYNOLDS, 1988; MAGURRAN, 2004). Both similarity indices were calculated using the Past software (HAMMER et al., 2001).

The body weight (Wt; g) and total length $(\mathrm{L} ; \mathrm{cm})$ data were used to calculate the relative condition factor $(\mathrm{Kn})$ of the host fish, as well as for determining the length-weight relationship $\left(W=\mathrm{aL}^{\mathrm{b}}\right)$ after logarithmic transformation of length and weight and subsequent adjustment of two straight lines, thereby obtaining $\ln y=\ln A+B \ln x($ LE CREN, 1951).

\section{Data analysis}

The Kolmogorov-Smirnov test was used to determine whether the parasite abundance data followed a normal distribution pattern. The differences in prevalence for each parasite infracommunity between $A$. falcatus and $A$. falcirostris were evaluated using the chi-square test $(\chi 2)$ with Yates correction; and the differences in parasite abundance using the Mann-Whitney test $(U)$. The comparisons of parasite prevalence and abundance were only made for parasites with prevalence $>10 \%$. For each host species, the differences in species richness, Shannon index $(H)$, evenness $(E)$ and Berger-Parker dominance index $(d)$ were determined using the Mann-Whitney test $(U)$. Spearman's coefficient $(r s)$ was used to investigate the correlation between length and the species richness, $H, E$, $d$ and abundance of the parasites, and the correlation between $\mathrm{Kn}$ and the abundance of the parasites (ZAR, 2010).

Principal component analysis (PCA) was carried out to compare the influence of body and diversity indices on the parasite communities of $A$. falcirostris and $A$. falcatus. This was done using the Past-Paleontological Statistics software, version 3.0 (HAMMER et al., 2001).

\section{Results}

All the specimens of $A$. falcirostris and $A$. falcatus were parasitized with one or more species and a total of 10 metazoan species occurred (Table 1). In A. falcatus, the dominant species was Piscinoodinium pillulare, while in A. falcirostris, it was Ichthyophthirius multifiliis (Table 2). The abundance of I. multifiliis, $P$. pillulare and Clinostomum marginatum (gills) had differences between $A$. falcirostris and $A$. falcatus. Prevalence of $P$. pillulare and Diaphorocleidus sp. was highest in A. falcatus. Braga patagonica was

Table 1. Parasites infracommunities for two species of Acestrorhynchidae from Brazilian Amazon.

\begin{tabular}{|c|c|c|c|c|c|c|c|}
\hline \multicolumn{2}{|l|}{ Host species } & \multicolumn{2}{|c|}{$\begin{array}{l}\text { Acestrorhynchus falcatus } \\
(\mathrm{n}=61)\end{array}$} & \multicolumn{4}{|c|}{$\begin{array}{l}\text { Acestrorhynchus falcirostris } \\
\qquad(\mathbf{n}=33)\end{array}$} \\
\hline Parasite species & SI & $\mathbf{P}(\%)$ & $\mathrm{MA} \pm \mathrm{SD}$ & $\mathbf{P}(\%)$ & $\mathrm{MA} \pm \mathrm{SD}$ & $\chi^{2}$ & $U$ \\
\hline Ichthyophthirius multifliis Fouquet, 1876 & Gills & 82.0 & $479.3 \pm 520.3$ & 78.8 & $6,125.7 \pm 10,162.4$ & 0.14 & $650.0^{*}$ \\
\hline Piscinoodinium pillulare Lom, 1981 & Gills & 78.7 & $3,205.5 \pm 4951.9$ & 3.0 & $163.7 \pm 883.4$ & $49.12^{* *}$ & $258.0^{* *}$ \\
\hline Diaphorocleidus sp. & Gills & 95.1 & $20.8 \pm 17.8$ & 72.7 & $30.6 \pm 33.4$ & $9.63^{* *}$ & 990.0 \\
\hline Dactylogyridae gen. sp. & Gills & 59.0 & $2.9 \pm 5.2$ & 36.4 & $2.3 \pm 4.7$ & 4.40 & 793.0 \\
\hline $\begin{array}{l}\text { Clinostomum marginatum Rudolphi, } 1819 \\
\text { (metacercariae) }\end{array}$ & Gills & 83.6 & $5.8 \pm 5.3$ & 84.8 & $57.1 \pm 192.7$ & 0.02 & $761.5^{*}$ \\
\hline Clinostomum marginatum (metacercariae) & Intestine & 13.1 & $0.9 \pm 4.3$ & - & - & - & - \\
\hline Digenea gen. sp. (metacercariae) & Intestine & - & - & 3.0 & $0.03 \pm 0.17$ & - & - \\
\hline Contracaecum sp. (larvae) & Intestine and liver & 93.4 & $9.4 \pm 29.3$ & 81.8 & $9.1 \pm 14.6$ & 3.25 & 924.5 \\
\hline Philometra sp. (larvae) & Intestine & 4.9 & $0.1 \pm 0.5$ & 3.0 & $0.03 \pm 0.17$ & - & - \\
\hline $\begin{array}{l}\text { Procamallanus (Spirocamallanus) inopinatus } \\
\text { Travassos, Artigas and Pereira, } 1928 \\
\text { (larvae and adults) }\end{array}$ & Intestine & 18.0 & $0.5 \pm 1.8$ & 39.4 & $1.2 \pm 2.5$ & $17.6^{* *}$ & 770.5 \\
\hline $\begin{array}{l}\text { Neochinorhynchus pterodoridis Thatcher, } 1981 \\
\text { (adults) }\end{array}$ & Intestine & 6.6 & $0.4 \pm 2.8$ & 6.1 & $0.9 \pm 3.7$ & - & - \\
\hline Braga patagonica Schödte and Meinert, 1884 & Gills & 1.6 & $0.03 \pm 0.26$ & - & - & - & - \\
\hline Ergasilus turucuyus Malta and Varella, 1996 & Gills & - & - & 3.0 & $0.03 \pm 0.17$ & - & - \\
\hline
\end{tabular}

The prevalence between hosts was compared using Chi-square test, and the abundance using Mann-Whitney test. P: Prevalence; MA: Mean abundance; SI: Site of infection; $\chi^{2}$ : Chi-square test; $U$ : Mann-Whitney test; ${ }^{*} \mathrm{p}<0.05$ and ${ }^{* *} \mathrm{p}<0.001$. 
only observed in $A$. falcatus, while Ergasilus turucuyus occurred only in $A$. falcirostris (Table 1 ).

The parasite species of $A$. falcatus and $A$. falcirostris presented an aggregated dispersion pattern, which is common among parasites of freshwater fish. Some species had higher values for the discrepancy index (Table 2), thus indicating greater parasite aggregation. The Shannon diversity index and the dominance index were similar for $A$. falcirostris and $A$. falcatus, but the mean species richness of parasites and the evenness were greater for A. falcatus (Table 3).

In both hosts, individuals parasitized by $4-7$ species predominated (Figure 2). Acestrorhynchus falcatus presented greater species richness per host and greater evenness, and the two hosts had similar structures for their parasite communities (Table 3).

In $A$. falcatus, length did not show any correlation with Shannon diversity index $(r s=0.13, \mathrm{p}=0.333)$, species richness of parasites $(r s=0.08, \mathrm{p}=0.54)$, evenness index $(r s=0.11, \mathrm{p}=0.39)$ or Berger-Parker dominance $(r s=-0.12, \mathrm{p}=0.35)$. However, in A. falcirostris, length was positively correlated with Shannon index ( $r s=0.35, \mathrm{p}=0.04)$, species richness $(r s=0.68, \mathrm{p}=0.0001)$ and evenness index $(r s=0.36, \mathrm{p}=0.04)$, but not with the Berger-Parker dominance index $(r s=-0.33, \mathrm{p}=0.05)$.

In $A$. falcirostris, Shannon index ( $r s=-0.53, \mathrm{p}=0.001)$ presented a significant negative correlation with $\mathrm{Kn}$, as did the richness of parasite species ( $r s=-0.48, \mathrm{p}=0.004$ ) with the $\mathrm{Kn}$ of the hosts. In $A$. falcatus, there was no significant correlation between Shannon index ( $r s=-0.04, \mathrm{p}=0.76)$ and $\mathrm{Kn}$, or between the richness of parasite species ( $r s=-0.18, \mathrm{p}=0.16$ ) and the Kn of the hosts.

In $A$. falcatus, length did not show any correlation with the abundance of $I$. multifliis ( $r s=0.22, \mathrm{p}=0.08$ ), P. pillulare ( $r s=0.01, \mathrm{p}=0.91)$, Diaphorocleidus sp. $(r s=0.15, \mathrm{p}=0.25)$, undetermined Dactylogyridae ( $r s=0.07, \mathrm{p}=0.61), C$. marginatum ( $r s=0.08, \mathrm{p}=0.52$ ), Procamallanus (Spirocamallanus) inopinatus ( $r s=-0.05, \mathrm{p}=0.69)$ or larvae of Contracaecum sp. ( $r s=-0.02$, $\mathrm{p}=0.85)$. The Kn also did not shown any correlation with the abundance of $I$. multifiliis ( $r s=0.14, \mathrm{p}=0.27)$, P. pillulare ( $r s=0.03$, $\mathrm{p}=0.76)$, Diaphorocleidus sp. $(r s=0.09, \mathrm{p}=0.48)$, undetermined Dactylogyridae $(r s=-0.16, \mathrm{p}=0.21), C$. marginatum $(r s=-0.03$, $\mathrm{p}=0.81), P$. $(S$. inopinatus $(r s=-0.20, \mathrm{p}=0.12)$ or Contracaecum ( $r s=0.007, \mathrm{p}=0.95)$.

In $A$. falcirostris, length presented a positive correlation with the abundance of Diaphorocleidus sp. $(r s=0.50, \mathrm{p}=0.003)$, undetermined Dactylogyridae ( $r s=0.47, \mathrm{p}=0.005), C$. marginatum (rs $=0.49, \mathrm{p}=0.004)$, Contracaecum sp. $(r s=0.40, \mathrm{p}=0.02)$ and P. $(S$. ) inopinatus $(r s=0.58, \mathrm{p}=0.0004)$. Length did not show any correlation with the abundance of $I$. multifliis ( $r s=0.14$, $\mathrm{p}=0.44)$. The Kn presented a positive correlation with the abundance of $I$. multifiliis ( $r s=0.49, \mathrm{p}=0.003$ ). The Kn showed

Table 2. Dispersion index (DI), $d$-statistic, discrepancy index (D) and frequency of dominance (FD) for the parasite infracommunities of two species of Acestrorhynchidae from Brazilian Amazon.

\begin{tabular}{|c|c|c|c|c|c|c|c|c|}
\hline \multirow{2}{*}{ Parasites } & \multicolumn{4}{|c|}{ Acestrorbynchus falcatus $(\mathrm{n}=61)$} & \multicolumn{4}{|c|}{ Acestrorhynchus falcirostris $(\mathrm{n}=33)$} \\
\hline & DI & $d$ & D & FD (\%) & DI & $d$ & $\mathbf{D}$ & FD (\%) \\
\hline Ichthyophthirius multifliis & 6.766 & 17.59 & 0.439 & 0.1286 & 5.498 & 10.83 & 0.465 & 0.9584 \\
\hline Piscinoodinium pillulare & 9.041 & 22.03 & 0.478 & 0.8603 & - & - & - & - \\
\hline Diaphorocleidus sp. & 5.168 & 14.00 & 0.389 & 0.0056 & 2.865 & 5.61 & 0.441 & 0.0048 \\
\hline Dactylogyridae gen. sp. & 3.040 & 8.19 & 0.596 & 0.0008 & 3.221 & 6.43 & 0.723 & 0.0004 \\
\hline Clinostomum marginatum (gills) & 2.959 & 7.94 & 0.424 & 0.0016 & 2.877 & 5.64 & 0.386 & 0.0089 \\
\hline Clinostomum complanatum (intestine) & 2.603 & 6.77 & 0.877 & 0.0003 & - & - & - & - \\
\hline Contracaecum sp. (intestine) & 3.497 & 9.58 & 0.598 & 0.0012 & 3.252 & 6.49 & 0.549 & 0.0008 \\
\hline Contracaecum sp. (liver) & 3.368 & 9.20 & 0.846 & 0.0004 & 2.509 & 4.74 & 0.840 & 0.0004 \\
\hline Contracaecum sp. (mesentery) & 4.224 & 11.61 & 0.723 & 0.0010 & 3.014 & 5.95 & 0.780 & 0.0004 \\
\hline Procamallanus (Spirocamallanus) inopinatus & 1.929 & 4.31 & 0.856 & 0.0001 & 1.554 & 2.04 & 0.706 & 0.0001 \\
\hline
\end{tabular}

Table 3. Characteristics of the component communities of parasites and body parameters for two species of Acestrorhynchidae from Brazilian Amazon.

\begin{tabular}{|c|c|c|c|c|}
\hline Mean indices & Acestrorhynchus falcatus & Acestrorhynchus falcirostris & $U$ & $\mathbf{p}$ \\
\hline Body length $(\mathrm{cm})$ & $19.5 \pm 1.5(16.0-23.0)$ & $22.1 \pm 4.8(12.5-28.5)$ & 561.5 & 0.0004 \\
\hline Body weight (g) & $76.5 \pm 16.1(26.0-115.0)$ & $87.8 \pm 44.4(15.0-156.0)$ & 719.0 & 0.023 \\
\hline Relative condition factor $(\mathrm{Kn})$ & $1.00 \pm 0.04(0.76-1.07)$ & $1.00 \pm 0.06(0.80-1.15)$ & 990.0 & 0.896 \\
\hline Species richness & $5.7 \pm 1.5(3-9)$ & $4.5 \pm 2.2(1-8)$ & 6.75 & 0.0086 \\
\hline Shannon index $(H)$ & $1.55 \pm 1.33(1.01-1.625)$ & $1.35 \pm 1.40(1.00-1.342)$ & 977.0 & 0.8152 \\
\hline Evenness $(E)$ & $0.22 \pm 0.14(0.004-0.648)$ & $0.14 \pm 0.16(0.000-0.550)$ & 1397.0 & 0.0002 \\
\hline Berger-Parker $(d)$ & $0.77 \pm 0.18(0.303-0.999)$ & $0.88 \pm 0.16(0.452-1.000)$ & 884.5 & 0.3338 \\
\hline Total number of parasites & 227,278 & 198,137 & - & - \\
\hline Number of ectoparasites & 6 & 6 & - & - \\
\hline Number of endoparasites & 5 & 5 & - & - \\
\hline Endoparasites (adult) & 2 & 2 & - & - \\
\hline Endoparasites (larval) & 5 & 5 & - & - \\
\hline
\end{tabular}

$U=$ Mann-Whitney test, $\mathrm{p}=$ Probability. 
a negative correlation with the abundance of Diaphorocleidus sp. $(r s=-0.46, \mathrm{p}=0.007)$, Dactylogyridae gen. sp. $(r s=-0.38$, $\mathrm{p}=0.02)$, Contracaecum sp. ( $r s=-0.42, \mathrm{p}=0.01$ and $C$. marginatum ( $r s=-0.47, \mathrm{p}=0.006$ ) The $\mathrm{Kn}$ also did not show any correlation with the abundance of $P$. $(S$. ) inopinatus ( $r s=-0.21, \mathrm{p}=0.25$ ).

The multivariate analysis of PCA based on the body and diversity parameters of $A$. falcirostris and $A$. falcatus showed that together the two main factors accounted for approximately $66 \%$ of the variance. The results showed that species richness of parasites, Shannon index and evenness were the main factors relating to A. falcatus, while the $\mathrm{Kn}$ and Berger-Parker dominance index were the factors most strongly relating to $A$. falcirostris (Figure 3).
The Jaccard index $\left(\mathrm{S}_{\mathrm{J}}=0.75\right)$ and Bray-Curtis dissimilarity $(\mathrm{BC}=0.17)$ demonstrated a high similarity between the parasite communities of $A$. falcirostris and $A$. falcatus. The multivariate analysis based on component communities of parasites for $A$. falcirostris and $A$. falcatus led to the observation that there was only a little separation between these species of hosts, caused by P. pillulare and I. multifiliis (Figure 4).

For $A$. falcatus, the equation for the weight/length relationship was $\mathrm{Wt}=0.207 \mathrm{~L}^{1.9853}\left(\mathrm{r}^{2}=0.438\right)$, while for $A$. falcirostris, it was $\mathrm{Wt}=0.0151 \mathrm{~L}^{2.7561}\left(\mathrm{r}^{2}=0.892\right)$; both of these were allometrically negative, thus indicating that there was a greater increase in body weight than in size. The relative condition factor $(\mathrm{Kn})$ of two hosts

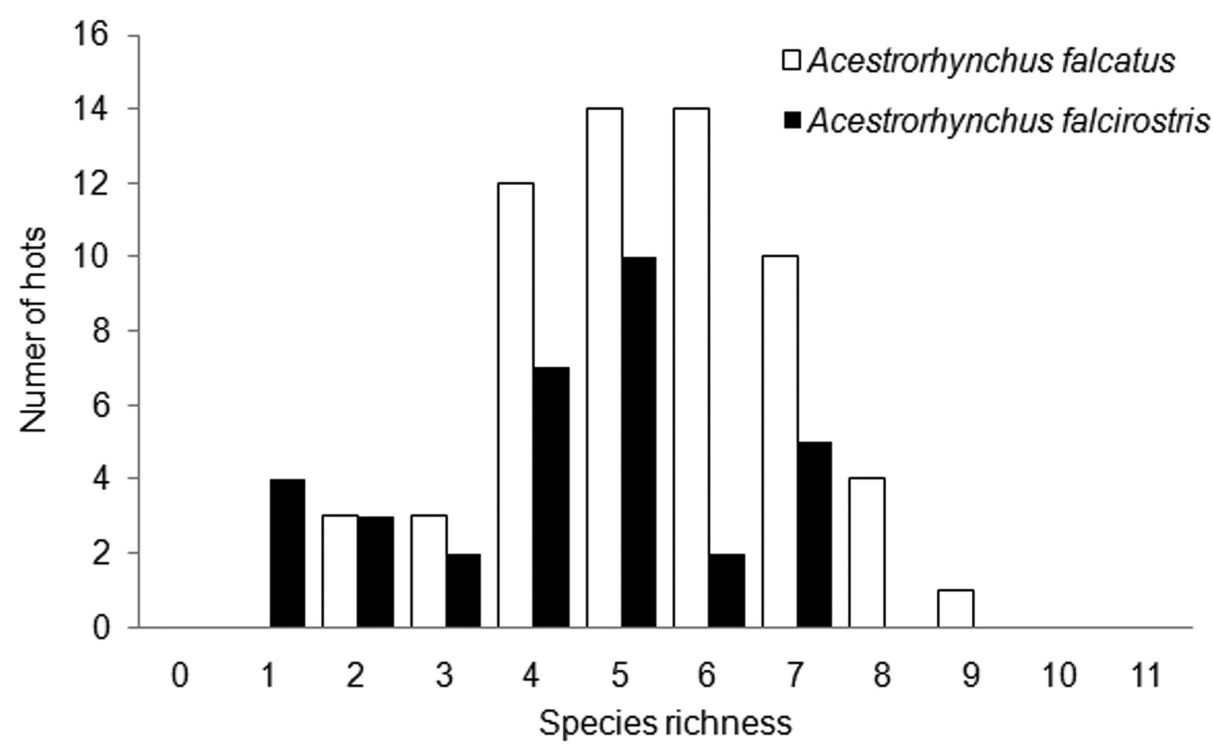

Figure 2. Species richness of parasites in two Acestrorhynchidae species from Brazilian Amazon.

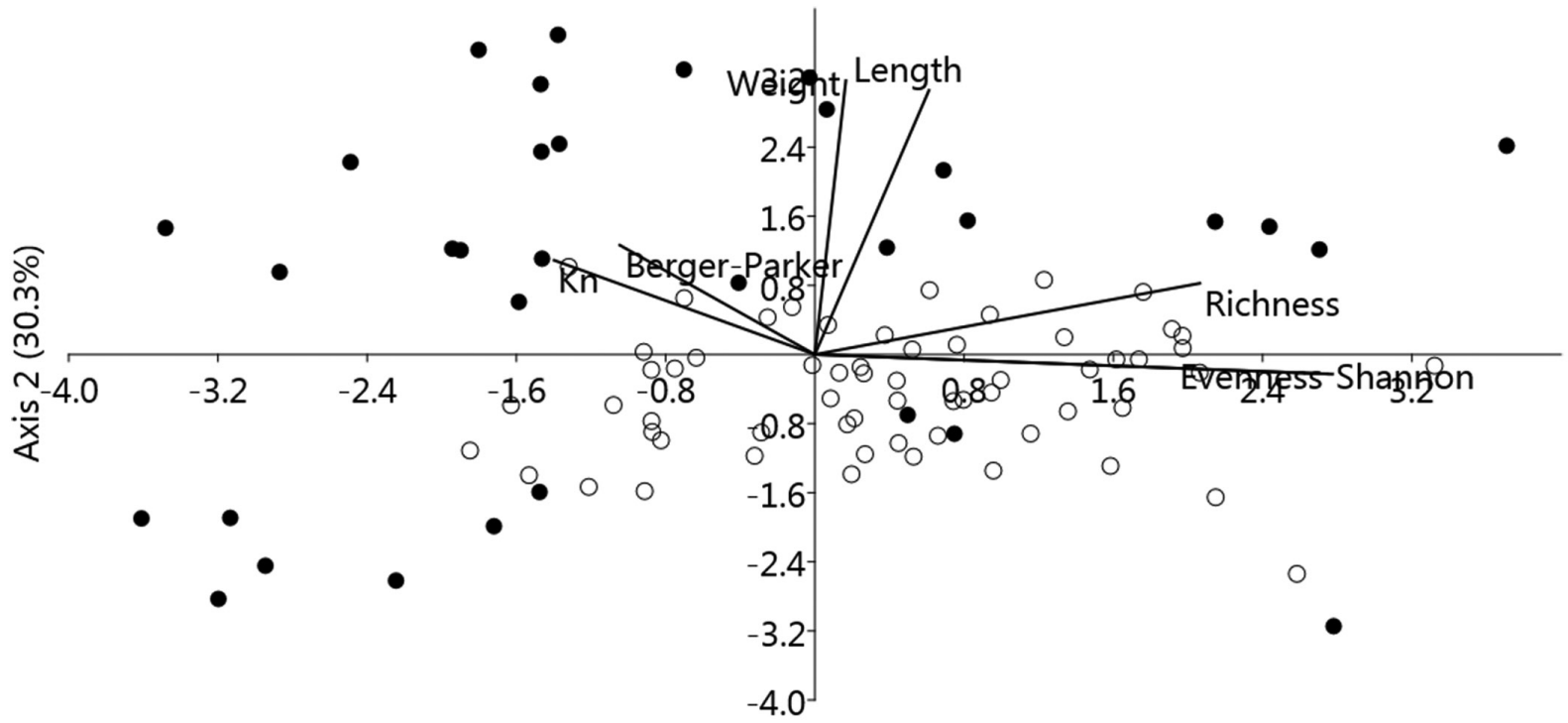

Axis $1(35.6 \%)$

Figure 3. Scatterplot scores of the principal component analysis (PCA) on factors influencing the parasite communities of Acestrorhynchus falcatus (०) and Acestrorhynchus falcirostris ( $\bullet$ ) from Brazilian Amazon. Kn: Relative condition factor, Shannon: Shannon diversity, Richness: species richness of parasites. 


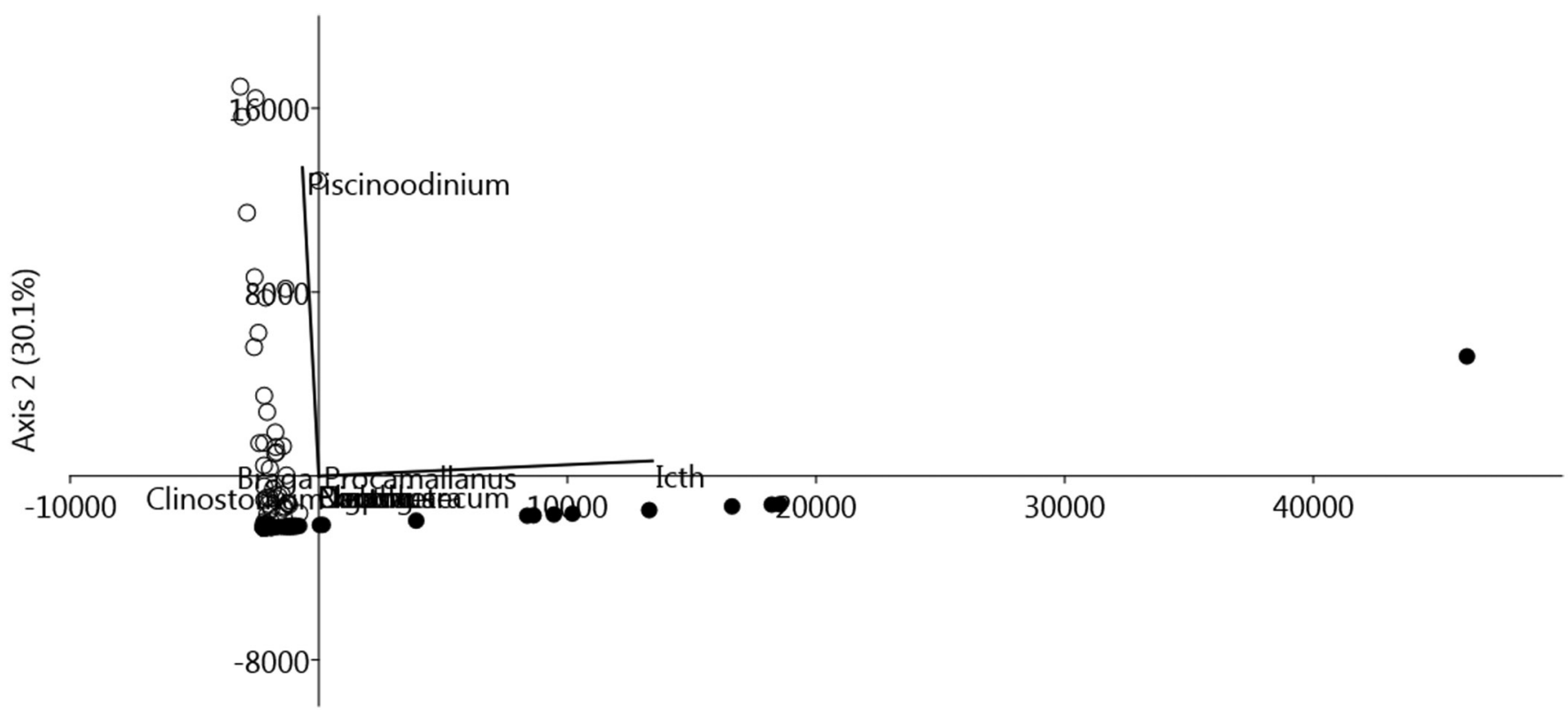

Axis 1 (69.9\%)

Figure 4. Scatterplot scores of the principal component analysis (PCA) on parasite communities of Acestrorhynchusfalcatus (O) and Acestrorhynchus falcirostris $(\bullet)$ from Brazilian Amazon. Icth: Ichthyophthirius multifliis, Piscinoodinium: Piscinoodinium pillulare, Diaph: Diaphorocleidus sp., Dacty: Dactylogyridae gen. sp., Clinostomum: Clinostomum marginatum, Contracaecum: Contracaecum sp.; Procamallanus: Procamallanus (Spirocamallanus) inopinatus, Braga: Braga patagonica, Ergasilus: Ergasilus turucuyus, Neoch: Neochinorhynchus pterodoridis.

was not different $(\mathrm{H}=1.126, \mathrm{p}=0.599)$ of the standard value $(\mathrm{Kn}=1.00)$, indicating therefore good body conditions despite the parasitism levels found.

\section{Discussion}

The parasite community structure of fish is mostly influenced by host physiology, ecology and phylogeny. Thus, hosts that live in the same environment and are phylogenetically related, with similar ecology, can be expected to have a certain degree of homogeneity in their parasite assemblages (MUNOZ et al., 2006; ALARCOS \& TIMI, 2012; PANTOJA et al., 2016). This is particularly so for endohelminths. However, ectoparasites and endoparasites species tend to respond differently both to environmental and to host-related variability (GONZÁLEZ \& OLIVA, 2006; ALARCOS \& TIMI, 2012; PANTOJA et al., 2016), given that transmission of ectoparasites is unaffected by feeding habits and ontogenetic changes in the hosts, or the availability of different prey species in the environment (GONZÁLEZ \& OLIVA, 2006; PANTOJA et al., 2016). This first investigation on the parasite communities in $A$. falcatus and $A$. falcirostris, which are species that live in the same environment and are phylogenetically related, showed that the parasite community was characterized by the presence of species with high prevalence, low abundance and predominance of ectoparasites (protozoans, monogenoideans and metacercariae of digeneans), but with similar endoparasites communities at the larval stage. The presence of adult endoparasites may be mostly related to the hosts' diet, while the presence of larval endoparasites may be due both to the hosts' diet and to predator-prey interactions, since this is the path through which many endoparasites species complete their heteroxenic life cycle (MUÑOZ et al., 2006; GUIDELLI et al., 2006; BITTENCOURT et al., 2014; PANTOJA et al., 2016). Therefore, these results indicate that for ectoparasites diversity, taxonomic proximity and phylogenetic proximity of the hosts are factors that are more important than host species-wide characteristics, and suggest that there is a similar relationship for endoparasites diversity.

Even if fish species that are phylogenetically related and live in the same environment have similar diversity of endoparasites, they may show differentiated levels of infection (MUNOZ et al., 2006; GUIDELLI et al., 2006; TAVARES \& LUQUE, 2008) in relation to ectoparasites species (PANTOJA et al., 2016). In A. falcatus, the dominant parasite species was P. pillulare, followed by I. multifiliis, but in $A$. falcirostris, the dominant species was I. multifiliis. Thus, both of the host species presented high prevalence and abundance of these protozoan ectoparasites. The size of the parasites is information of relevance for understanding how much parasite biomass can be sustained by hosts, and how this can determine the parasite community structure. Thus, the protozoa I. multifiliis and $P$. pillulare exhibited much higher parasite burden than did the other parasite species, probably due to the small size, low specificity and high reproduction and infection rates of these ectoparasites (NEVES et al., 2013).

In the gills of $A$. falcirostris, the abundance of $I$. multifiliis and metacercariae of $C$. marginatum was higher than in $A$. falcatus. The latter host showed higher prevalence and abundance of $P$. pillulare and 
higher prevalence of Diaphorocleidus sp. These differences between the hosts may have been caused by heterogeneity of the host-parasite relationship. This would have been influenced by biological factors, especially those relating to the reproduction period, since fish suffer higher stress levels during this period (SCHRECK, 2010; ROHLENOVÁ \& SIMKOVÁ, 2010) and are more susceptible to parasitic infections, especially due to opportunistic parasites like the protozoa found here. For $A$. falcirostris, the abundance of monogenoideans, Contracaecum sp., $P$. (S.) inopinatus and $C$. marginatum increased with the length of the hosts, indicating therefore that larger individuals accumulated greater quantities of these parasites. Moreover, hosts with lower body conditions showed higher abundance of monogenoideans, Contracaecum sp. and $C$. marginatum. In contrast, the length of the population of $A$. falcatus did not show any correlation of abundance with any of the parasites, or between the condition factor and the diversity and richness of parasite species, because of the homogeneity of size of specimens of this host that were examined. Nonetheless, the presence of larger parasite infracommunities in larger fish has been a common characteristic in host-parasite systems (POULIN \& FITZGERALD, 1987; CARVALHO et al., 2003; MUNÓZ et al., 2006; GONZÁLEZ \& OLIVA, 2006; GUIDELLI et al., 2006; PANTOJA et al., 2016).

Diversity values depend on the balance within species richness between dominant species (ALARCOS \& TIMI, 2012). Larvae of Contracaecum sp. were the endoparasites with most importance as contributors towards abundance and species richness in $A$. falcatus and $A$. falcirostris, while C. marginatum, $P$. (S.) inopinatus, Philometra sp. and Neoechinorhynchus pterodoridis had little importance. Acestrorhynchus falcirostris showed lower parasite richness per host and a lower evenness, besides the Shannon diversity index and evenness showed a weak correlation with the size of the hots. Principal component analysis proved that the $\mathrm{Kn}$ and Berger-Parker dominance index were the main factors relating to $A$. falcirostris. In contrast, there was no correlation between the size of $A$. falcatus and the diversity indexes, since the population sampled comprised a larger number of individuals and the body size was relatively homogenous and bigger than in the population of $A$. falcirostris, although $A$. falcatus is a fish of smaller body size (SOARES et al., 2011). Moreover, principal component analysis showed that in $A$. falcatus, Shannon diversity, species richness of and evenness were the main factors relating to this host. Despite these differences in body size between $A$. falcirostris and $A$. falcatus, there were no differences in body condition, prevalence, abundance, richness and diversity of endoparasites in these two populations if piscivorous hosts of similar age. Moreover, the Kn indicated good body condition and general health for $A$. falcirostris and $A$. falcatus. In host-parasite networks, the host body provides a microhabitat for ectoparasites and endoparasites species (GUIDELLI et al., 2006; BELLAY et al., 2013). It has been suggested that high parasite species diversity may be an indicator of individual fish growth and body condition. In addition, correlations between the richness and abundance of parasites and host body size have commonly been reported in studies on component communities (POULIN \& FITZGERALD, 1987; CARVALHO et al., 2003; GUIDELLI et al., 2006; GONZÁLEZ \& OLIVA, 2006; ALARCOS \& TIMI, 2012; NEVES et al., 2013; PANTOJA et al., 2016). Nevertheless, it has been argued that wild fish populations with higher density may provide more trophic host-parasite interactions, besides sustaining a larger population of endoparasites (TAKEMOTO et al., 2005; GUIDELLI et al., 2006).

Parasites are typically found in communities in which different species coexist in fish of the same host species or in different host species (MUÑOZ et al., 2006; TAVARES \& LUQUE, 2008; BELLAY et al., 2013; ALCÂNTARA \& TAVARES-DIAS, 2015). Protozoan and monogenoidean ectoparasites are parasites typical of lentic environments, but their reproduction is strongly favored by eutrophized environments like the hydrographic basin of this study (TAKIYAMA et al., 2012). Some crustaceans are host and site-specific, especially in relation to fish with particular habitats and lifestyles, while other parasites frequently have no preference (TAVARES-DIAS et al., 2015). However, isopods of B. patagonica were found only on the gills of $A$. falcatus, and those of $E$. turucuyus only in $A$. falcirostris. Consequently, these isopod species were the parasites of lowest prevalence and abundance in these hosts, because they found their hosts using their ability to swim or their close relationship with them (TAVARES-DIAS et al., 2015). In $A$. falcatus, the dominant species was $P$. pillulare, while in $A$. falcirostris, it was I. multifiliis. The ectoparasites and endoparasites found in these two hosts presented an aggregated dispersion pattern, but I. multifliis, P. pillulare, Contracaecum, C. marginatum and P. (S.) inopinatus presented the greatest aggregation (> discrepancy), in both hosts. This overdispersion is a common pattern of ectoparasites and endoparasites infracommunities in different fish populations (POULIN \& FITZGERALD, 1987; NEVES et al., 2013; TAVARES-DIAS et al., 2015; PANTOJA et al., 2016), and is caused by a diversity of factors (see ROHDE et al., 1995; POULIN, 2013; TAVARES-DIAS et al., 2015).

The parasite communities in $A$. falcirostris and $A$. falcatus were formed by parasite species common to other species of freshwater fish (CARVALHO et al., 2003; GUIDELLI et al., 2006; NEVES et al., 2013; BITTENCOURT et al., 2014; TAVARES-DIAS et al., 2015; PANTOJA et al., 2016). Neochinorhynchus pterodoridis collected from $A$. falcatus and $A$. falcirostris is an acanthocephalan species that was described originally from Pterodoras granulosus Humboldt and Valenciennes 1821, a siluriform Doradidae (THATCHER, 1981). For the two host populations studied here, the structure of the component community was constituted especially by species of generalist parasites, with a direct or indirect life cycle. Therefore, our findings suggest that the interaction pattern of $A$. falcatus and A. falcirostris with the endoparasites found (acanthocephalans, digeneans and nematodes) is closely associated with their diet. In addition, they suggest that the observed parasites diversity is unrelated to host-parasite coevolution, therefore indicating that there is no need to focus future research towards the historical processes shaping these relationships. This is the first record of I. multifiliis, P. pillulare, C. marginatum, Diaphorocleidus sp., Contracaecum, Philometra sp., P. (S.) inopinatus and N. pterodoridis in $A$. falcirostris and $A$. falcatus.

In conclusion, the present study demonstrated that there was low diversity of parasites and similar parasites communities in $A$. falcatus and $A$. falcirostris. The parasites infracommunities of both were rich in species, with presence of protozoans, crustaceans, monogenoideans, digeneans, nematodes and acanthocephalans. 
In general, larval helminths that are transmitted trophically, with low or nonexistent parasitic specificity among fish species, they infected these fish as paratenic hosts or as intermediate hosts. They may live in these hosts for long periods, thus persisting in the food chain. Thereby, these characteristics make them potentially available for any fish host, independent of its trophic level. It is clear that parasite species with the highest abundance are not the largest species, and that few species of helminths are numerically important. This can be connected to resources and the niche needed for each species. Endoparasites abundance and diversity were mostly influenced by the similar amounts and types of prey that they were eating (crustaceans and mollusks). Finally, the same geographic occurrence area (sympatry) of these two related hosts also played an important role in the parasite communities found. Therefore, these two host fish competes with each other, because they do not exhibit differences in feeding.

\section{Acknowledgements}

Dr. MarcosTavares-Dias was supported by research fellowships from the Conselho Nacional de Pesquisa e Desenvolvimento Tecnológico (CNPq, Brazil).

\section{References}

Alarcos AJ, Timi JT. Parasite communities in three sympatric flounder species (Pleuronectiformes: Paralichthyidae): similar ecological filters driving toward repeatable assemblages. Parasitol Res 2012; 110(6): 21552166. http://dx.doi.org/10.1007/s00436-011-2741-5. PMid:22167375.

Alcântara NM, Tavares-Dias M. Structure of the parasites communities in two Erythrinidae fish from Amazon River system (Brazil). Rev Bras Parasitol Vet 2015; 24(2): 183-190. http://dx.doi.org/10.1590/S198429612015039. PMid:26083690.

Bellay S, Oliveira EF, Almeida-Neto M, Lima DP Jr, Takemoto RM, Luque JL. Developmental stage of parasites influences the structure of fish-parasite networks. PLoS One 2013; 8(10): e75710. http://dx.doi. org/10.1371/journal.pone.0075710. PMid:24124506.

Bittencourt LS, Pinheiro DA, Cárdenas MQ, Fernandes BMM, TavaresDias M. Parasites of native Cichlidae populations and invasive Oreochromis niloticus (Linnaeus, 1758) in tributary of Amazonas River (Brazil). Rev Bras Parasitol Vet 2014; 23(1): 44-54. http://dx.doi.org/10.1590/S198429612014006. PMid:24728360.

Bush AO, Lafferty KD, Lotz JM, Shostak AW. Parasitology meets ecology on its own terms: Margolis et al. revisited. J Parasitol 1997; 83(4): 575583. http://dx.doi.org/10.2307/3284227. PMid:9267395.

Carvalho S, Guidelli GM, Takemoto RM, Pavanelli GC. Ecological aspects of endoparasite fauna of Acestrorhynchus lacustris (Lütken, 1875) (Characiformes, Acestrorhynchidae) on the upper Paraná River floodplain, Brazil. Acta Sci Biol Sci 2003; 25(2): 479-483. http://dx.doi.org/10.4025/ actascibiolsci.v25i2.2043.

Eiras JC, Takemoto RM, Pavanelli GC. Métodos de estudo e técnicas laboratoriais em parasitologia de peixes. Maringá: Eduem; 2006.

Froese R, Pauly D, editors. FishBase version 1/2016 [online]. FishBase; 2016 [cited 2015 Oct 10]. Available from: www.fishbase.org
Gama CS, Halboth DA. Ictiofauna das ressacas das bacias do Igarapé da Fortaleza e do Rio Curiaú, In: Takiyama LR, Silva AQ. Diagnóstico das ressacas do estado do Amapá: bacias do Igarapé da Fortaleza e Rio Curiaú. Macapá: CPAQ/IEPA/DGEO/SEMA; 2004. p. 23-52.

González MT, Oliva ME. Similarity and structure of the ectoparasite communities of rockfish species from the southern Chilean coast in a temporal scale. Parasitology 2006; 133(3): 335-343. http://dx.doi. org/10.1017/S0031182006000370. PMid:16753080.

Guidelli G, Tavechio WLG, Takemoto RM, Pavanelli GC. Fauna parasitária de Leporinus lacustris e Leporinus friderici (Characiformes, Anostomidae) da planície de inundação do alto Rio Paraná, Brasil. Acta Sci Biol Sci 2006; 28(3): 281-290.

Hammer O, Harper DAT, Ryan PD. PAST: paleontological statistics software package for education and data analysis. Palaeontol Electronica 2001; 4(1): 1-9.

Le Cren ED. The length-weight relationship and seasonal cycle in gonad weight and condition in the perch (Perca fluviatilis). J Anim Ecol 1951; 20(2): 201-219. http://dx.doi.org/10.2307/1540.

Ludwig JA, Reynolds JF. Statistical ecology: a primer on methods and computing. New York: Wiley-Interscience; 1988.

Magurran AE. Measuring biological diversity. Oxford: Blackwell Science; 2004 .

Muñoz G, Grutter AS, Cribb TH. Endoparasite communities of five fish species (Labridae: Cheilininae) from Lizard Island: how important is the ecology and phylogeny of the hosts? Parasitology 2006; 132(3): 363-374. http://dx.doi.org/10.1017/S0031182005009133. PMid:16332286.

Neves LR, Pereira FB, Tavares-Dias M, Luque JL. Seasonal influence on the parasite fauna of a wild population of Astronotus ocellatus (Perciformes: Cichlidae) from the Brazilian Amazon. J Parasitol 2013; 99(4): 718-721. http://dx.doi.org/10.1645/12-84.1. PMid:23421456.

Pantoja WMF, Silva LVF, Tavares-Dias M. Are similar the parasite communities structure of Trachelyopterus coriaceus and Trachelyopterus galeatus (Siluriformes: Auchenipteridae) in the Amazon basin? Rev Bras Parasitol Vet 2016; 25(1): 46-53. http://dx.doi.org/10.1590/S198429612016016. PMid:27007248.

Poulin R, Fitzgerald GJ. The potential of parasitism in the structuring of a salt marsh stickleback community. Can J Zool 1987; 65(11): 27932798. http://dx.doi.org/10.1139/z87-421.

Poulin R. Explaining variability in parasite aggregation levels among host samples. Parasitology 2013; 140(4): 541-546. http://dx.doi.org/10.1017/ S0031182012002053. PMid:23343821.

Pretti VQ, Calcagnotto D, Toledo-Piza M, Almeida-Toledo LF. Phylogeny of the Neotropical genus Acestrorhynchus (Ostariophysi: Characiformes) based on nuclear and mitochondrial gene sequences and morphology: A total evidence approach. Mol Phylogenet Evol 2009; 52(2): 312-320. http://dx.doi.org/10.1016/j.ympev.2008.12.025. PMid:19168140.

Rohde K, Hayward C, Heap M. Aspects of the ecology of metazoan ectoparasites of marine fishes. Int J Parasitol 1995; 25(8): 945-970. http://dx.doi.org/10.1016/0020-7519(95)00015-T. PMid:8550295.

Rohlenová K, Simková A. Are the immunocompetence and the presence of metazoan parasites in cyprinid fish affected by reproductive efforts of Cyprinid fish? J Biomed Biotechnol 2010; 2010: 418382. http://dx.doi. org/10.1155/2010/418382. PMid:20145709. 
Rózsa L, Reiczigel J, Majoros G. Quantifying parasites in samples of hosts. J Parasitol 2000; 86(2): 228-232. http://dx.doi.org/10.1645/00223395(2000)086[0228:QPISOH]2.0.CO;2. PMid:10780537.

Schreck CB. Stress and fish reproduction: the roles of allostasis and hormesis. Gen Comp Endocrinol 2010; 165(3): 549-556. http://dx.doi. org/10.1016/j.ygcen.2009.07.004. PMid:19596332.

Silva AT, Goitein R. Diet and feeding activity of Acestrorhynchus lacustris (Lütken, 1875) (Characiformes, Acestrorhynchidae) in the water reservoir at Ribeirão Claro, SP. Braz J Biol 2009; 69(3): 757-762. http://dx.doi. org/10.1590/S1519-69842009000400002. PMid:19802434.

Soares MGM, Costa EL, Siqueira-Souza FK, Anjos HDB, Yamamoto KC, Freitas CEC. Peixes de lagos do médio Rio Solimóes. 2nd ed. Manaus: Reggo Edições; 2011.

Takemoto RM, Pavanelli GC, Lizama MA, Luque JL, Poulin R. Host population density as the major determinant of endoparasite species richness in floodplain fishes of the upper Paraná River, Brazil. J Helminthol 2005; 79(1): 75-84. http://dx.doi.org/10.1079/JOH2004264. PMid:15831117.
Takiyama LR, Silva URL, Jimenez EA, Pereira RA, Zacardi DM, Fernandes $\mathrm{EF}$, et al. Zoneamento ecológico econômico urbano das áreas de ressacas de Macapá e Santana, Estado do Amapá. Macapá: IEPA; 2012.

Tavares LER, Luque JL. Similarity between metazoan parasite communities of two sympatric brackish fish species from Brazil. J Parasitol 2008; 94(4): 985-989. http://dx.doi.org/10.1645/GE-1460.1. PMid:18576803.

Tavares-Dias M, Dias-Júnior MB, Florentino AC, Silva LM, Cunha AC. Distribution pattern of crustacean ectoparasites of freshwater fish from Brazil. Rev Bras Parasitol Vet 2015; 24(2): 136-147. http://dx.doi. org/10.1590/S1984-29612015036. PMid:26154954.

Thatcher VE. Neochinorhynchus pterodoridis n. sp. (Acanthocephala: Neochinorhynchidae) do bacu liso (Pterodoras granulosus) da Amazônia Brasileira. Acta Amazon 1981; 11(3): 445-448.

Toledo-Piza M. Phylogenetic relationships among Acestrorhynchus species (Ostariophysi: Characiformes: Acestrorhynchidae). Zool J Linn Soc 2007; 151(4): 691-757. http://dx.doi.org/10.1111/j.1096-3642.2007.00355.x.

Zar JH. Biostatistical analysis. 5th ed. New Jersey: Prentice Hall; 2010. 